\title{
Hubungan Kualitas Produk, Harga, dan Lokasi Terhadap Kepuasan Pelanggan pada Toko Rifki Busana Dalam Rangka Pemasaran Online
}

\author{
Safri \& Iswandir \\ zrsafri@yahoo.co.id, Iswandir11@gmail.com
}

\begin{abstract}
Based on data processing using SPSS 22, obtained multiple correlation coefficient $(R)=0.972$, so there is a strong or positive relationship between Product Quality, Price and Location on Customer Satisfaction at Rifki Busana Store, Jakarta, Determination Coefficient $(R 2)=97,2 \%$ so that $2,8 \%$ is influenced by other factors not examined in this study. To obtain multiple regression values $Y=3.828+0.387 X_{1}+0.335 X_{2}+0.486 X_{3}$ and for the test with a level of confidence $\alpha=5 \%$ obtained $t$ value of 1.692 so that there is a significant positive effect between variables $X_{1}$ to $Y$, and that there is a significant positive Significantly between variables $X_{2}$ to $Y$, and there is a significant positive effect between variables $X_{3}$ to $Y$, Ho is rejected and $\mathrm{Ha}$ is accepted, which means there is an influence of Product Quality, Price, and Location on the Customer. Satisfaction. As well as for the F-test with a level of confidence $\alpha=5 \%$, the $F$ value is obtained from 0,000 which is smaller than the trust value which means that the variables $X 1, X 2, X 3$ together have a significant effect on variables equal to $Y$. Therefore, it can be concluded that the model the regression used in this study is valid

Keywords: Product Quality, Price, Location, Customer satisfaction
\end{abstract}

\section{PENDAHULUAN}

\section{A. Latar Belakang Masalah}

Dengan berkembang pesatnya bisnis online di Indonesia alur distribusi barang dan jasa mengalami perkembangan yang signifikan, berbagai macam bentuk bisnis, reseller, dan dropshopers mulai bermunculan seiring dengan adanya peningkatan kebutuhan konsumen terhadap produk tertentu. Bisnis retail telah mengalami perubahan yang sangat pesat, terjadi peralihan dari konsep toko-toko lokal mapan atau toko di "jalur utama", toko yang berskala nasional dalam bentuk pusat-pusat perbelanjaan modern berupa supermarket, hypermarket, toko serba ada dan sebagainya ataupun toko-toko kecil, menjajakan produknya diruang online. Pertumbuhan tempat perbelanjaan ke ruang maya yang pesat memudahkan konsumen dalam memilih tempat untuk berbelanja hanya tinggal klik saja, kapanpun dan dimanapun.

Bagi toko besar dengan modal besar relatif mudah untuk mendirikan usaha online, sedangkan bagi toko-toko maupun perusahaan retail (eceran) merupakan tantangan yang harus dijawab untuk tetap bertahan pada bisnisnya. 
Terdapat bisnis yang telah maju dan mapan, namun ada juga perusahaan berskala relatif besar yang belum sempat berkembang bahkan mati pada bisnis online ini. Toko-toko kecil dengan sendirinya dapat bersaing dengan toko-toko besar dilihat dari segi apapun pada bisnis ini, namun yang perlu diperhatikan adalah kesiapan dari toko-toko kecil dalam menjalankan usaha.

\section{B. Identifikasi Masalah}

Dari latar belakang masalah tersebut, maka dapat di identifikasikan beberapa masalah, antara lain sebagai berikut:

1. Kualitas produk Toko Rifki Busana Jakarta.

2. Harga produk Toko Rifki Busana Jakarta.

3. Lokasi Toko Rifki Busana Jakarta kurang diketahui keberadaannya oleh masyarakat.

4. Kepuasan pelanggan Toko Rifki Busana Jakarta dari kualitas produk, harga, dan lokasi.

\section{Rumusan Masalah}

Berdasarkan identifikasi masalah tersebut, maka penulis merumuskan beberapa rumusan sesuai dengan judul penelitian ini. adalah:

1. Apakah ada pengaruh antara kualitas produk terhadap kepuasan pelanggan di Toko Rifki Busana Jakarta?

2. Apakah ada pengaruh antara harga terhadap kepuasan pelanggan Toko Rifki Busana Jakarta?
3. Apakah ada pengaruh antara lokasi terhadap kepuasan pelanggan Toko Rifki Busana Jakarta?

4. Apakah ada pengaruh antara kualitas produk, harga, dan lokasi secara bersama-sama terhadap kepuasan pelanggan Toko Rifki Busana Jakarta?

\section{LANDASAN TEORI}

A. Tinjauan Teori

1. Pemasaran

Menurut Philip Kotler dan Gary Amstrong, pemasaran adalah sebagai proses sosial dan manager yang membuat individu dan kelompok memperoleh apa yang mereka butuhkan dan inginkan lewat penciptaan dan pertukaran timbal balik produk dan nilai dengan orang lain.

\section{Kualitas Produk}

Menurut Philip Kotler dan Keller, terdapat lima tingkatan produk, antara lain:

a. Manfaat inti (core benefit), adalah layanan atau manfaat sesungguhnya yang dbeli pelanggan.

b. Produk dasar (basic Product), Pemasar harus mengubah manfaat inti menjadi produk dasar.

c. Produk yang diharapkan (Expected Product), Yaitu beberapa atribut dan kondisi yang biasanya diharapkan pembeli ketika mereka membeli produk.

d. Produk yang ditingkatkan (Augmented Product) Pada 
tingkat ini produk melampaui harapan pelanggan.

e. Calon produk (Potential Product) Meliputi segala kemungkinan peningkatan dan perubahan atau tawaran tersebut pada masa mendatang.

Menurut Kotler dan Armstrong (2012:283) kualitas produk adalah:

Kemampuan sebuah produk dalam memperagakan fungsinya, hal ini termasuk keseluruhan durabilitas, reliabilitas, ketepatan, kemudahan pengoperasian, dan reparasi produk, juga atribut produk lainnya.

Salah satu nilai utama yang diharapkan oleh pelanggan dari produsen adalah kualitas produk dan jasa yang tertinggi.

Menurut American Society for Quality Contro (Kotler, Marketing Management, 11th Edition. Prentice Hall Int'l, New Jersey, 2003;84), kualitas adalah keseluruhan ciri serta sifat suatu produk atau pelayanan yang berpengaruh pada kemampuannya untuk memuaskan kebutuhan yang dinyatakan atau tersirat. Untuk menentukan kualitas produk, menurut Kotler (2010:361) kualitas produk dapat dimasukkan ke dalam 9 dimensi, yaitu:

a. Bentuk (Form) produk dapat dibedakan secara jelas dengan yang lainnya berdasarkan bentuk, ukuran, atau struktur fisik produk.

b. Ciri-ciri produk (Features) karakteristik sekunder atau pelengkap yang berguna untuk menambah fungsi dasar yang berkaitan pilihanpilihan produk dan pengembangannya.

c. Kinerja (Performance) berkaitan dengan aspek fungsional suatu barang dan merupakan karakterisitik utama yang dipertimbangkan pelanggan dalam membeli barang tersebut.

d. ketepatan/kesesuaian (Conformance) Berkaitan dengan tingkat kesesuaian dengan spesifikasi yang ditetapkan sebelumnya berdasarkan keinginan pelanggan. Kesesuaian merefleksikan derajat ketepatan antara karakteristik desain produk dengan karakteristik kualitas standar yang telah ditetapkan.

e. Ketahanan (durabillity) Berkaitan dengan berapa lama suatu produk dapat digunakan.

f. Kehandalan (reliabillity) Berkaitan dengan probabilitas atau kemungkinan suatu barang berhasil menjalankan fungsinya setiap kali digunakan dalam periode waktu tertentu dan dalam kondisi tertentu pula. 
g. Kemudahan perbaikan (repairabillity) Berkaitan dengan kemudahan perbaikan atas produk jika rusak. Idealnya produk akan mudah diperbaiki sendiri oleh pengguna jika rusak.

h. Gaya (Style), Penampilan produk dan kesan konsumen terhadap produk.

i. Desain (design) Keseluruhan keistimewaan produk yang akan mempengaruhi penampilan dan fungsi produk terhadap keinginan konsumen.

Menurut Boetsh dan Denis yang dikutip oleh Tjiptono (2000:57): Kualitas merupakan suatu kondisi dinamis yang berhubungan dengan produk, jasa, manusia, proses dan lingkungan yang memenuhi atau melebihi harapan. Pendapat di atas dapat dimaksudkan bahwa seberapa besar kualitas yang diberikan yang berhubungan dengan produk barang beserta faktor pendukungnya memenuhi harapan penggunanya. Dapat diartikan bahwa semakin memenuhi harapan konsumen, produk tersebut semakin berkualitas.

Relevan dengan pendapat diatas, Clark (2000:5) mendefinisikan kualitas sebagai" how consistenly the product or service delivered meets or exceeds the customer's (internal or eksternal) expectation and needs" (seberapa konsisten produk atau jasa yang dihasilkan dapat memenuhi pengharapan dan kebutuhan internal dan eksternal pelanggan).

\section{Harga}

Perilaku pembelian mencari keragaman dalam situasi yang mempunyai karakter keterlibatan konsumen rendah, tetapi anggapan perbedaan merek yang signifykan. Dalam kasus ini, konsumen sering melakukan banyak pertukaran merek. Pemimpin pasar akan mencoba mendorong perilaku pembeli kebiasaan dengan mendominasi ruang rak, membuat rak tetap penuh, dan menjalankan iklan untuk mengingatkan konsumen sesering mungkin. Perusahaan penantang akan mendorong pencarian keragaman dengan menawarkan harga yang lebih murah, kesepakatan kupon khusus, sampel gratis, dan iklan yang menampilkan alasan untuk mencoba sesuatu yang baru.

Kotler dan Keller (2007: 76) mengungkapkan pengertian harga merupakan: "Harga adalah salah satu unsur bauran pemasaran yang menghasilkan pendapatan."

\section{Lokasi}

Basu Swasta dan Irawan (2008;339) "Lokasi adalah 
letak atau toko pengecer pada daerah yang strategis sehingga dapat memaksimumkan laba". Sedangkan menurut Prasetya dan Lukiastuti (2009;135) menyatakan bahwa "penentuan lokasi sangat menentukan suatu kelangsungan hidup perusahaan dimasa yang akan datang".

\section{Kepuasan Pelanggan}

Day (Tjiptono, 2004) mendefinisikan kepuasan atau ketidakpuasan konsuman adalah respon konsuman terhadap evaluasi ketidak sesuaian/diskonfirmasi yang dirasakan antara harapan sebelumnya (atau norma kerja lainnya) dan kinerja aktual produk yang dirasakan setelah pemakaiannya. Kepuasan konsuman adalah suatu keadaan dimana keinginan, harapan dan kebutuhan konsuman dipenuhi. produk,

\section{B. Penelitian Terdahulu}

1. Wahyudin, Drs. Aris Slamet Widodo SP. M.sc / Sutrisno, SP.MP Program studi Agribisnis, Fakultas Pertanian Universitas Muhammadiyah Yogyakarta. Tahun 2017 Dengan hasil Kualitas produk, harga, dan lokasi secara simultan mempengaruhi kepuasan pelanggan.

2. Eko Purnomo, Program studi Manajemen, Fakultas Ekono$\mathrm{mi}$, Universitas Pasir Pengaraian, tahun 2016, dengan hasil produk, harga, dan lokasi mempunyai pengaruh positif dan signifikan terhadap kepuasan pelanggan.

3. Rina Sukmawati, Prodi Pendidian Ekonomi, Fakultas Ekonomi, Universitas Negeri Yogyakarta, tahun 2017 dengan hasil terdapat pengaruh positif dan signifikan dari variabel kualtas produk, harga dan kulitas pelayanan terhadap kepuasan konsumen.

\section{Paradigma Penelitian}

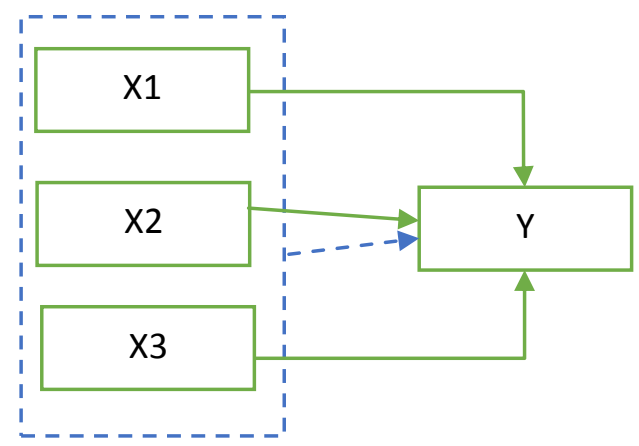

\section{Hipotesis}

Dugaan atau jawaban sementara dari penelitian atas permasalahan yang perlu dibuktikan dengan analisa data adalah sebagai berikut:

1. $\mathrm{H}_{1}$ : Terdapat pengaruh antara kualitas produk terhadap kepuasan pelanggan Toko Rifki Busana Jakarta.

2. $\mathrm{H}_{2}$ : Terdapat pengaruh antara harga terhadap kepuasan pelanggan Toko Rifki Busana Jakarta.

3. $\mathrm{H}_{3}$ : Terdapat pengaruh antara lokasi terhadap kepuasan pelanggan Toko Rifki Busana Jakarta.

4. $\mathrm{H}_{4}$ : Terdapat pengaruh antara kualitas produk, harga, 
dan lokasi secara bersama-sama terhadap kepuasan pelanggan Toko Rifki Busana Jakarta.

\section{E. METODELOGI PENELITIAN}

1. Variabel Bebas

Variabel yang mempengaruhi variabel lain dan berkorelasi dengan permasalahan yang diteliti. Terdapat tiga yang menjadi variabel bebas yaitu Kualitas Produk $\left(X_{1}\right)$, $\operatorname{Harga}\left(X_{2}\right)$, dan Lokasi $\left(\mathrm{X}_{3}\right)$

2. Variabel Terikat

Variabel terikat adalah variabel yang dipengaruhi oleh variabel bebas, yang menjadi variabel terikat atau variabel $Y$ dalam penelitian ini adalah Kepuasan Pelanggan.

3. Populasi dan Sampel

Prof. Sugiyono (2008, 72). Populasi adalah wilayah generalisasi yang terdiri atas objek atau subjek yang mempunyai kualitas dan karakteristik tertentu yang ditetapkan oleh peneliti untuk dipelajari dan kemudian ditarik kesimpulannya. Jumlah Populasi dari penelitian ini tidak diketahui.

Prof. Sugiyono (2013, 116). Sampel adalah bagian dari jumlah dan karakteristik yang dimiliki oleh populasi tersebut. Atas jumlah populasi tidak dapat diketahui tersebut maka sampel diambil secara Simple Random Sampling sebanyak 52 responden.
III. HASIL PENELITIAN

\section{Uji Reliabilitas}

a. Uji Reliabilitas Kualitas Produk

Dari hasil uji reliabilitas pada variabel Kualitas Produk, nilai cronbach's alpha 0.782 $>0.600$. Jadi dapat disimpulkan bahwa pernyataan dalam kuesioner yang diajukan adalah (reliable) dan layak untuk dianalisis.

b. Uji Reliabilitas Harga

Dari hasil uji reliabilitas pada variabel Harga, nilai cronbach's alpha $0.687>$ 0.600 . Jadi dapat disimpulkan bahwa pernyataan dalam kuesioner yang diajukan adalah (reliable) dan layak untuk dianalisis.

\section{c. Uji Reliabilitas Lokasi}

Dari hasil uji reliabilitas pada variabel fasilitas, nilai cronbach's alpha $0.752>$ 0.600 . Jadi dapat disimpulkan bahwa pernyataan dalam kuesioner yang diajukan adalah (reliable) dan layak untuk dianalisis.

d. Uji Reliabilitas Kepuasan Pelanggan.

Dari hasil uji reliabilitas pada variabel kepuasan pelanggan, nilai cronbach's alpha $0.785>0.600$. Jadi dapat disimpulkan bahwa pernyataan dalam kuesioner yang diajukan adalah (reliable) dan layak untuk dianalisis.

\section{Uji Validitas}

a. Uji Validitas Variabel Kualitas Produk 
Hasil pengujian diatas menunjukkan bahwa butir-butir pertanyaan pada kuesioner Kualitas Produk, menunjukkan r-hitung > r-tabel maka dapat disimpulkan bahwa semua butir pertanyaan adalah valid.

b. Uji Validitas Variabel Harga Hasil pengujian diatas menunjukkan bahwa butir-butir pertanyaan pada kuesioner Harga, menunjukkan $r$ hitung $>$ r-tabel maka dapat disimpulkan bahwa semua butir pertanyaan adalah valid.

c. Uji Validitas Variabel Lokasi Hasil pengujian diatas menunjukkan bahwa butir-butir pertanyaan pada kuesioner Lokasi, menunjukkan rhitung >r-tabel maka dapat disimpulkan bahwa semua butir pertanyaan adalah valid.

d. Uji Validitas Variabel Kepuasan Pelanggan

Hasil pengujian diatas menunjukkan bahwa butir-butir pertanyaan pada kuesioner Kepuasan Pelanggan, menunjukkan r-hitung > r-tabel maka dapat disimpulkan bahwa semua butir pertanyaan adalah valid.

\section{Uji Asumsi Klasik}

a. Uji Normalitas

1. Kualitas Produk $\left(X_{1}\right)$

Pada pengujian kualitas produk meggunakan Kolmogorov-Smimov dengan nilai probabilitas signifikan 0,475 (Asymp. Sig. 2-tailed). Berdasar- kan data olahan, variabel kualitas produk telah memenuhi syarat normalitas yaitu dengan nilai probabilitas $>0,05$ maka data variabel kualitas produk adalah normal dan dapat digunakan dalam penelitian.

2. Harga $\left(X_{2}\right)$

Pada pengujian kualitas harga meggunakan Kolmogorov-Smimov dengan nilai probabilitas signifikan 0,625 (Asymp. Sig. 2-tailed). Berdasarkan data olahan, variabel harga telah memenuhi syarat normalitas yaitu dengan nilai probabilitas $>0,05$ maka data variabel harga adalah normal dan dapat digunakan dalam penelitian.

3. Lokasi $\left(X_{3}\right)$

Pada pengujian lokasi meggunakan

Kolmogorov-Smimov dengan nilai probabilitas signifikan 0,378 (Asymp. Sig. 2-tailed). Berdasarkan data olahan telah memenuhi syarat normalitas yaitu dengan nilai probabilitas $>0,05$ maka data variabel lokasi adalah normal dan dapat digunakan dalam penelitian.

4. Kepuasan Pelanggan $(\mathrm{Y})$ Pada pengujian kepuasan pelanggan meggunakan Kolmogorov-Smimov dengan nilai probabilitas signifikan 0,395 (Asymp. 
Sig. 2-tailed). Berdasarkan data olahan telah memenuhi syarat normalitas yaitu dengan nilai probabilitas > 0,05 maka data variabel kepuasan pelanggan adalah normal dan dapat digunakan dalam penelitian.

\section{b. Uji Multikolinearitas}

Pengujian menggunakan uji multikolinearitas diperoleh nilai Variance Inflation Factor (VIF) masing-masing variabel pada output SPSS 22 tabel Coefficients yaitu, nilai kualitas produk sebesar 6,725 , harga sebesar 7,800 dan lokasi sebesar 13,750 tidak ada yang melebihi nilai 10. Dengan demikian, dapat disimpulkan bahwa pada regresi antara variabel bebas kualitas produk $\left(X_{1}\right)$, harga $\left(X_{2}\right)$ dan lokasi $\left(X_{3}\right)$ terhadap kepuasan pelanggan $(\mathrm{Y})$ tidak terjadi multikolinearitas antara variabel bebas.

\section{c. Uji Heterokedastisitas}

Pengujian

Heterokedastisitas hasil output SPSS 22 gambar Scatterplot menunjukkan penyebaran titik-titik data:

1. Titik-titik data menyebar di atas dan di bawah atau di sekitar angka 0 .

2. Titik-titik data tidak mengumpul hanya di atas atau di bawah saja.

3. Penyebaran titik-titik data tidak membentuk pola bergelombang melebar kemudian menyempit dan melebar kembali.

4. Penyebaran titik-titik data tidak berpola.

Kesiimpulnya model regresi linier berganda bebas dari asumsi klasik heteroskedastisitas dan layak digunakan dalam penelitian.

\section{Hasil Analisis Data}

Pengujian hipotesis dalam penelitian ini dengan menggunakan dua uji regresi, yaitu uji regresi sederhana dengan uji t-test nilai $p$ value kolom Sig., dan uji regresi secara simultan dengan uji $F$-test.

a. Uji regresi dengan t-test

1) Uji Regresi Kualitas Produk Terhadap Kepuasan Pelanggan.

Dari penelitian yang dilakukan bahwa adanya pengaruh kualitas produk terhadap kepuasan pelanggan yang dibuktikan berdasarkan uji regresi parsial yang menghasilkan uji signifikansi dengan uji t sebesar 4.682 lebih besar dari pada $t$ tabel yaitu sebesar 1,692 atau dengan kata lain $\mathrm{t}$ hitung $>\mathrm{t}$ tabel (4.682>1.692). Kesimpulannya $\mathrm{H}_{\mathrm{a}}$ diterima dan $\mathrm{H}_{0}$ ditolak.

2) Uji Regresi Harga Terhadap Kepuasan Pelanggan.

Dari penelitian yang dilakukan bahwa adanya pengaruh harga terhadap kepuasan pelanggan yang dibuktikan berdasar- 
kan uji regresi parsial yang menghasilkan uji signifikansi dengan uji $\mathrm{t}$ sebesar 2.972 lebih besar dari pada $\mathrm{t}$ tabel yaitu sebesar 1.692 atau dengan kata lain $\mathrm{t}$ hitung $>\mathrm{t}$ tabel (2.972 > 1.692). Kesimpulannya bahwa $\mathrm{H}_{\mathrm{a}}$ diterima dan $\mathrm{H}_{0}$ ditolak.

3) Uji Regresi Lokasi Terhadap Kepuasan Pelanggan.

Dari penelitian yang dilakukan bahwa adanya pengaruh lokasi terhadap kepuasan pelanggan yang dibuktikan berdasarkan uji regresi parsial yang menghasilkan uji signifikansi dengan uji $t$ sebesar 3,107 lebih besar dari pada t tabel yaitu sebesar 1,692 atau dengan kata lain $\mathrm{t}$ hitungah $>\mathrm{t}$ tabel $(3,107>1,692)$. Kesimpulan bahwa $\mathrm{H}_{\mathrm{a}}$ diterima dan $\mathrm{H}_{\mathrm{o}}$ ditolak.

4) Uji Regresi Berganda Kualitas Produk, Harga, dan Lokasi Terhadap Kepuasan Pelanggan Memiliki pengaruh yang signifikan antara kualitas produk, harga, dan lokasi terhadap kepuasan pelanggan

\section{b. Uji Simultan F-Test}

Berdasarkan hasil uji ANOVA diperoleh Fhitung 307,442 dan nilai Ftabel sebesar 2,926 maka Fhitung $>$ Ftabel dengan signifikansi 0,000 dimana nilai tersebut $<\quad 0,05$. Kesimpulannya
Kualitas Produk, Harga, dan Lokasi secara bersamasama berpengaruh signifikan terhadap Kepuasan Pelanggan.

\section{SIMPULAN DAN SARAN}

\section{a. Kesimpulan}

Berdasarkan analisis dan pembahasan, maka dapat ditarik kesimpulan sebagai berikut:

1. Kualitas produk memiliki pengaruh signifikan terhadap kepuasan pelanggan. Dibuktikan dengan hasil Tabel distribusi dengan df (n-k) yaitu 52 dan dengan dua sisi $(\alpha=0,05)$ diperoleh nilai $t_{\text {tabel }}$ sebesar 1,692. Sehingga diketahui bahwa hasil $t_{\text {hitung }}>t_{\text {tabel }}$ dan didapat notasi $(18,858$ $>2,176$ ). sehingga $\mathrm{Ho}_{1}$ ditolak dan $\mathrm{Ha}_{1}$ diterima. Serta diketahui bahwa uji secara parsial menghasilkan nilai probabilitas signifikansi sebesar 0,000 yang lebih kecil dari $\alpha=0,05$, atau dengan $t_{\text {hitung }}$ yang diperoleh untuk Kualitas Produk 18,858 (bernilai positif).

2. Harga memiliki pengaruh signifikan terhadap kepuasan pelanggan. Di buktikan dengan Tabel distribusi dengan df (n-k) yaitu 52 dan dengan dua sisi ( $\alpha=0,05$ ) diperoleh nilai $t_{\text {tabel }}$ sebesar 1,692. Sehingga diketahui bahwa hasil $t_{\text {hitung }}>t_{\text {tabel }}$ dan didapat notasi $(18,858>$ $2,176)$. Sehingga $\mathrm{Ho}_{2}$ di- 
tolak dan $\mathrm{Ha}_{2}$ diterima. Serta diketahui bahwa uji secara parsial menghasilkan nilai probabilitas signifikansi sebesar 0,000 yang lebih kecil dari $\alpha=0,05$, atau dengan $t_{\text {hitung }}$ yang diperoleh untuk Harga 18,858 (bernilai positif).

3. Lokasi memiliki pengaruh yang signifikan terhadap Kepuasan Pelanggan. Dibuktikan dari Tabel distribusi dicari dengan df $(n-k)$ yaitu 52 dan dengan dua $\operatorname{sisa}(\alpha=0,05) \quad$ diperoleh nilai $t_{\text {tabel }}$ sebesar 1,692 . Sehingga diketahui bahwa hasil $t_{\text {hitung }}>t_{\text {tabel }}$ dan didapat notasi $(18,858>$ 1,692). Sehingga $\mathrm{Ho}_{3}$ ditolak dan $\mathrm{Ha}_{3}$ diterima. Serta diketahui bahwa uji secara parsial menghasilkan nilai probabilitas signifikansi sebesar 0,000 yang lebih kecil dari $\alpha=0,05$, atau dengan $t_{\text {hitung }}$ yang diperoleh untuk Lokasi 18,858 (bernilai positif).

4. Dari hasil uji Anova atau $\mathrm{F}$ test didapat nilai $F_{\text {hitung }}$ sebesar 307,442 dengan tingkat keyakinan 95\% (menggunakan $\alpha=5 \%$ ), df1 (jumlah variabel 1) $=3$, df2 $(n-k-1)=52$, dan diperoleh hasil $F_{\text {tabel }}$ sebesar 2.926 Maka dapat dikatakan bahwa $F_{\text {hitung }}>$ $F_{\text {tabel }}$ yaitu 307,442>2.926. Dari tabel diatas diperoleh probabilitas (tingkat signifi- kansi) 0,000. Oleh karena probabilitas 0,000 lebih kecil dari 0.05 , Sehingga Ho ditolak dan Ha diterima. Sehingga dapat dikatakan bahwa Kualitas Produk, Harga dan Lokasi secara bersama-sama (simultan) berpengaruh terhadap Kepuasan Pelanggan. Atas hal tersebut diatas maka toko Rifki Busana Jakarta sudah selayaknya untuk menambah bentuk pemasarannya berupa pemasaran secara online.

\section{b. Saran}

Dari hasil penelitian yang telah dilakukan, maka ada beberapa saran guna meningkatkan kepuasan pelanggan di Toko Rifki Busana Jakarta untuk dapat bersaing di pemsaran online:

1. Bagi Toko Rifki Busana Jakarta agar dapat mempertahankan Kualitas Produknya. Sehingga dapat mempertahankan bahkan meningkatkan Kepuasan Pelanggan.

2. Bagi Toko Rifki Busana diharapkan Harga yang ditetapkan saat ini untuk produk yang dijualnya. Sehingga bisa mempertahankan bahkan meningkatkan Kepuasan Pelanggan.

3. Bagi Toko Rifki Busana diharapkan Lokasi penjualan di media online untuk segera dilakukan, baik membuat web sendiri ataupun menggunakan kepada media pemasaran online yang sudah ada.

4. Untuk penelitian selanjutnya diharapkan menambah 
variabel bebas lainnya yang mungkin berkontribusi besar terhadap kepuasan pelanggan seperti promosi, difersifikasi produk, ekuitas merek, di dan lain-lain.

\section{DAFTAR PUSTAKA}

$\begin{array}{cr}\text { Hermawan Kartajaya. } & 2002 . \\ \text { Hermawan Kartajaya } & \text { On } \\ \text { Marketing, Jakarta } & \text { PT. } \\ \text { Gramedia Pustaka Utama. } & \end{array}$

Hermawan Kartajaya. 2004.

Positioning, Diferensiasi, dan

Brand. Jakarta PT. Gramedia

Pustaka Utama

Kotler, Philip. Marketing

Management, 11th Edition.

Prentice Hall Int'l, New Jersey, 2003,

Kotler, Philip, dan Kevin Lane Keller. 2009. Manajemen Pemasaran
Jilid 1, edisi Ketiga Belas, Terjemahan Bob Sabran, MM. Jakarta: Penerbit Erlangga.

Kotler, Philip and Gary Amstrong, 2008, $\quad$ Prinsip-prinsip Pemasaran edisi 12, jilid 1. Jakarta; Erlangga

Lupiyoadi, Rambat dan Hamdani, A. (2008). Manajemen Pemasaran Jasa. Edisi 2. Jakarta. Salemba Empat.

Oentoro, Deliyanti. (2010). Manajemen Pemasaran Modern. Samarinda

Sugiyono. (2009). Metode Penelitian Bisnis. Alfabeta. Bandung

Tjiptono, Fandy, \& Chandra, Gregorius (2011). Service, Quality, and Satisfaction edisi ketiga. Andi Jakarta 